\title{
Nutrient and sensory analysis of analog rice made with arrowroot (Maranta arundinaceae) flour, germinated red kidney bean (Phaseolus vulgaris $L$ ) flour, germinated white sorghum flour, and sago starch
}

\author{
*Nugraheni, M., Purwanti, S. and Ekawatiningsih, P. \\ Culinary Art Education Department, Yogyakarta State University
}

\begin{abstract}
Article history:
Received: 8 June 2020

Received in revised form: 16 July 2020

Accepted: 9 August 2020

Available Online: 3 October 2020
\end{abstract}

\section{Keywords:}

Analog rice,

Arrowroot,

Germinated,

Red kidney bean,

White Sorghum

\section{DOI:}

https://doi.org/10.26656/fr.2017.4(6).269

\begin{abstract}
This research was aimed to analyze the chemical characteristics and sensory evaluation of analog rice. The manufacture of analog rice was done by formulating the tuber's flour, cereal, and legume. A sensory evaluation was performed with a hedonic test. The chemical characteristics of analog rice analyzed were the content of protein, lipid, moisture, ash, amylose, amylopectin, dietary fiber, resistant starch, and calculating the amount of energy. The results showed that analog rice development was done by conducting three formulations with a percentage of different composition on the constituent ingredients. The ingredients were arrowroot (Maranta arundinaceae) flour, modified arrowroot flour rich in resistant starch, germinated of red kidney bean (Phaseolus vulgaris L) flour, germinated of white sorghum flour, sago starch, hydrocolloid, GMS, water, and oil. The hedonic test indicated that the selected formulation was the third formulation. The nutrients content of selected analog rice were moisture: $9.71 \pm 0.05 \%$; ash: $3.38 \pm 0.01 \%$, protein: $8.07 \pm 0.04 \%$, lipid: $1.01 \pm 0.01 \%$, dietary fiber: $19.81 \pm 0.45 \%$, carbohydrate: $68.74 \pm 0.01 \%$, resistant starch: $3.43 \pm 0.02 \%$, amylose: $18.25 \pm 0.04 \%$, amylopectin: $49.94 \pm 0.13 \%$ and energy: $308.24 \pm 0.14 \mathrm{cal} / 100 \mathrm{~g}$.
\end{abstract}

\section{Introduction}

The dependence on wheat flour and rice cause Indonesia to be vulnerable to food insecurity. Need to diversify food based on local potentials by developing analog rice. The development of analog rice can be directed into a functional diet. It contains high-quality nutrients, is sensory accepted by the community and has specific functional properties. Analog rice formulations based on local foodstuffs, i.e., cereal, legumes, and tuber, are expected to have specifications: high in protein, digestible starch, and fiber, so it is expected to have a positive impact for healthy consuming.

Analog rice has a major carbohydrate-rich main component. The composition of analog rice consists of starch, fiber, fats, water, binders, other additives, dyes, flavors, phosphorus, and antioxidants (Budijanto and Yuliana, 2015). The development of analog rice-based carbo-local non-rice requires modifying the process, i.e., cereal and legumes, and the autoclaving-cooling process for three cycles of tuber composite flour aimed at increasing the resistance levels of starch.

The developed analog rice should be sensory acceptable by the society of color, shape, aroma, and taste. A sensory evaluation of analog rice should be conducted. The form and physical properties are expected to approach the original rice but have high protein, fiber, and resistant starch, containing bioactive compounds, and have a low glycemic index. The precise formulation of the composite starch, legumes, and cereal is necessary to produce a nutritional, sensory-acceptable analog rice with functional properties.

Specifications of analog rice produced are high levels of resistant starch. To provide the specification, the local potential flour-based arrowroot (Maranta arundinacea) contains a high level of RS3 with autoclaving-cooling three cycles. The autoclavingcooling process of tuber-based flour manufacturing can increase resistant starch (Lilia et al., 2016).

The resulting analog rice specification is high in protein, fiber and has a low glycemic index. To produce such specifications used cereal (Sorghum), legume (red kidney bean/Phaseolus vulgaris $L$ ) is a protein and fiber source. Research shows show that red bean fiber and protein are $7.86 \%, 17.37 \%$, respectively (Sai-Ut et al., 
2009). Sorghum's protein content was $10.62 \%$, and fiber was $6.7 \%$ (Subagyo and Aqil., 2014). The low glycemic index can be obtained from food containing protein, fiber, and high resistant starch (Alsaffar, 2011; Bisharat et al., 2015). The extrusion process followed by drying makes the starch not digested by digestive enzymes, thereby producing a low glycemic response (Al Dhaheri et al., 2015).

The sensory characteristics of the developed analog rice must be acceptable to the community. However, the use of cereals and legumes often affects the scent and taste of the resulting product. It usually has an off-flavor and bitter taste (due to tannins) that can decrease the community's acceptance level. The modification of the process can decrease the aroma and bitter taste of products based on cereal and legumes and reduce antinutritional factors (trypsin inhibitors, phytic acid, Pentosan, and tannins) (Zhang et al., 2015; Sharma et al., 2016).

Modification of the constituent materials and processing process is expected to produce analog rice developed as a local potential based functional food. The study was aimed to determine the chemical characteristic and sensory analysis of rice analog enriched with arrowroot flour, modified arrowroot flour with resistant starch type 3, germinated red kidney bean flour and germinated white sorghum flour.

\section{Materials and methods}

\subsection{Arrowroot flour}

The arrowroot was thinly sliced, washed and dried in the cabinet dryer at $50^{\circ} \mathrm{C}$ for $24 \mathrm{hrs}$ until the moisture content reached $12 \%$. Then, the dried arrowroot slices were milled and sieved with the Tyler sieve Mesh 80 .

\subsection{Modified arrowroot flour with resistant starch type 3}

Arrowroot flour rich in resistant starch type 3 content was made by three autoclaving-cooling cycles (Nugraheni et al., 2017). The arrowroot flour was dissolved in $20 \%$ water $(\mathrm{w} / \mathrm{v})$ and heated with stirring at $70^{\circ} \mathrm{C}$ to form a paste. The pasted was then autoclaved at $121^{\circ} \mathrm{C}$ for 15 mins and cooled for $1 \mathrm{hr}$ for 3 cycles. The final cooled paste was stored in the refrigerator at $4^{\circ} \mathrm{C}$ for $24 \mathrm{hrs}$. The paste was then dried in the cabinet dryer until the water content reached $12 \%$. The dried pasted was then milled and sieved with Tyler sieve mesh 80 .

\subsection{Germinated red kidney bean flour}

The red kidney beans (Phaseolus vulgaris L) germination process was referred to Audu and Aremu (2011). Good quality red kidney beans were selected and cleaned. The beans were then soaked for $8 \mathrm{hrs}$ in water at the ratio of 1: $3(\mathrm{w} / \mathrm{w})$. The basin containing the soaked beans was closed using a folded cloth and store in the dark space during the soaking process. Water spraying was done for every $6 \mathrm{hrs}$ to retain moisture of the red kidney beans. After $24 \mathrm{hrs}$, the germinated red kidney beans were dried in the cabinet dryer at $50^{\circ} \mathrm{C}$ for $24 \mathrm{hrs}$. The dried beans were milled and sieved using the Tyler Mesh 80.

\subsection{Germinated white sorghum flour}

The germination of white sorghum was referred to Elkhalifa and Bernhardt (2010). Good quality white sorghum was selected and cleaned. Then, it was soaked for $8 \mathrm{hrs}$ in water at the ratio of 1: $3(\mathrm{w} / \mathrm{w})$. The basin containing the soaked sorghum was closed using a folded cloth and store in the dark space during the soaking process. Water spraying was done for every $6 \mathrm{hrs}$ to retain moisture of the germinating sorghum. After $36 \mathrm{hrs,}$ the germinated sorghum was dried in the cabinet dryer at $50^{\circ} \mathrm{C}$ for $24 \mathrm{hrs}$. The dried beans were milled and sieved using the Tyler Mesh 80.

\subsection{Analog rice formulations}

A total of three formulations of analog rice was produce in this study. The main materials used were arrowroot flour, modified arrowroot flour with resistant starch type 3, germinated red kidney beans flour, germinated white sorghum flour and sago flour. Hydrocolloid, glyceryl monostearate, water and coconut oil were added as ingredients. Dry ingredients were first mixed evenly and then the liquids were added in. The semi-wet bater formed was steamed for 40 mins and extruded into rice grain-like shape.

\subsection{Sensory evaluation}

A total of thirty panelists performed the sensory evaluation on the analog rice. Analog rice samples were prepared with the following steps: rice grains were rinsed twice, soaked for 10 mins to allow even distribution of moisture, and steamed for 20 mins. Using a 9-point hedonic scale $(9$ - extremely like to 1 - extremely dislike), panelists were asked to rank for color, aroma, flavor, texture and overall acceptability.

\subsection{Proximate analysis}

The chemicals analysis carried out were moisture content, ash content, fat content with soxhlet, protein levels with Kjeldahl methods (AOAC, 2005), and carbohydrate levels with by difference. Amylose and amylopectin determination were referred to AOAC (2005) while resistant starch content referred to by Englyst (1992) and Hallstrom et al. (2011). 


\subsection{Statistical analysis}

Data were presented in the form of average \pm standard deviation. The advanced Variant analysis was done with the least significant difference test at $p<0.05$ using the SPSS version 16.0 (SPSS Inc., South Wacker Drive, Chicago, United States of America).

\section{Results and discussion}

\subsection{Formulation and development of analog rice}

The formulation begins with the preparation of raw materials used to make analog rice (Table 1). Arrowroot flour was modified via three cycles of autoclavingcooling cycles to increase the resistant starch level. The germination process of red kidney beans and sorghum will lower the aroma and unwanted flavors of cereals and nuts and increase the protein content. The dry ingredients were mixed first and added with supporting ingredients such as glycerol monostearate, hydrocolloid, coconut oil and water.

Glyceryl monostearate functions as a lubricant during production to reduce the heat of the extrusion process, making the analog rice to not stick with one another and reducing the expansion but increase the water absorption index (Kaur et al., 2005). The glyceryl monostearate will bind with amylose forming a helix structure (Alsaffar, 2011). In addition, it functions as a carbohydrate source in analog rice.

The manufacture of analog rice is done by extrusion technology (Mishra et al., 2012) because it is very active in terms of process and produces analog rice resembling rice grains. According to Riaz (2000), the extrusion principle is the process of food processing. It combines several continuous processes such as mixing, heating with high temperature, dough, shearing, and forming through mold (die) to develop extrusion results. The hot extrusion technology uses temperatures above $70^{\circ} \mathrm{C}$ obtained from steam, or electric heaters (elements) mounted around the barrel and friction between the dough material and the barrel and screw (Mishra et al., 2012)

\subsection{Sensory evaluation}

The analog rice developed was a bit beige which is different from rice. The texture of analog rice formulation III was closest to the commercial rice. Overall, analog rice formulation III was most liked compared to other formulations (Table 2). All analog rice produced a distinct aroma, i.e. beany flavor and offflavor (Mishra et al., 2017), detectable by the panelists. It was known that the beany, bitter and off-flavor in the analog rice cannot be reduced to a minimal even though the legumes have undergone the germination. Nevertheless, the analog rice was still acceptable.

\subsection{Proximate analysis}

The proximate analysis of the analog rice of each formulation was tabulated in Table 3. The favored analog rice by panelists (Formulation III) was shown to have more nutritional content and other beneficial compounds. The nutritional components are derived from diverse raw materials which will benefit the body and health. The presence of fat and protein can form a food matrix with amylose, which affects the slowdown rate of gastric discharge to reduce digestibility (Alsaffar, 2011).

The resistant starch content in analog rice was at $3.83 \pm 0.02 \%, \quad 4.12 \pm 0.01 \%, \quad$ and $3.43 \pm 0.02 \%$ for formulation I, formulation II and formulation III respectively while commercial rice recorded only $0.94 \%$. Resistant is an insoluble dietary fiber which cannot be digested by the colon but can be slowly fermented by the bowel's microflora. A slow gastrointestinal process affects the delay in blood glucose enhancement, controls

Table 1. Ingredient composition of the formulations of analog rice

\begin{tabular}{lccc}
\hline Composition & $\begin{array}{c}\text { Formulation I } \\
\text { (proportion) }\end{array}$ & $\begin{array}{c}\text { Formulation II } \\
\text { (proportion) }\end{array}$ & $\begin{array}{c}\text { Formulation III } \\
\text { (proportion) }\end{array}$ \\
\hline Arrowroot flour & 7 & 6 & 5 \\
Modified arrowroot flour with resistant starch type 3 & 1 & 1 & 1 \\
Red kidney bean flour & 4 & 4 & 4 \\
White sorghum flour & 4 & 4 & 4 \\
Sago starch & 4 & 5 & 6 \\
\hline
\end{tabular}

Table 2. Sensory evaluation of the formulations of analog rice

\begin{tabular}{lccccc}
\hline & Color & Aroma & Taste & Texture & Overall \\
\hline Formulation I & $4.80 \pm 0.41^{\mathrm{a}}$ & $4.13 \pm 0.73^{\mathrm{b}}$ & $4.93 \pm 0.78^{\mathrm{b}}$ & $4.80 \pm 0.76^{\mathrm{b}}$ & $4.97 \pm 0.93^{\mathrm{b}}$ \\
Formulation II & $4.80 \pm 0.41^{\mathrm{a}}$ & $3.93 \pm 0.58^{\mathrm{a}}$ & $3.83 \pm 0.65^{\mathrm{a}}$ & $4.00 \pm 0.87^{\mathrm{a}}$ & $3.93 \pm 0.79^{\mathrm{a}}$ \\
Formulation III $^{5.93 \pm 0.74^{\mathrm{b}}}$ & $5.90 \pm 0.71^{\mathrm{c}}$ & $5.93 \pm 0.64^{\mathrm{c}}$ & $6.17 \pm 0.65^{\mathrm{c}}$ & $6.67 \pm 0.76^{\mathrm{c}}$ \\
\hline
\end{tabular}

Values are expressed as mean \pm SD. Values with different superscripts within the same column are significantly different $(\mathrm{p}<0.05)$. 
Table 3. Proximate analysis of the formulations of analog rice

\begin{tabular}{lccc}
\hline & Formulation I & Formulation II & Formulation III \\
\hline Water content (\%) & $7.67 \pm 0.02^{\mathrm{a}}$ & $8.70 \pm 0.08^{\mathrm{b}}$ & $9.71 \pm 0.05^{\mathrm{c}}$ \\
Ash (\%) & $3.69 \pm 0.17^{\mathrm{c}}$ & $2.99 \pm 0.04^{\mathrm{a}}$ & $3.38 \pm 0.01^{\mathrm{b}}$ \\
Protein (\%) & $8.77 \pm 0.04^{\mathrm{b}}$ & $8.93 \pm 0.04^{\mathrm{c}}$ & $8.07 \pm 0.04^{\mathrm{a}}$ \\
Lipid (\%) & $0.97 \pm 0.07^{\mathrm{a}}$ & $1.09 \pm 0.12^{\mathrm{b}}$ & $1.01 \pm 0.01^{\mathrm{a}}$ \\
Carbohydrate (\%) & $69.55 \pm 0.16^{\mathrm{c}}$ & $69.48 \pm 0.15^{\mathrm{b}}$ & $68.74 \pm 0.01^{\mathrm{a}}$ \\
Amylose (\%) & $18.99 \pm 0.05^{\mathrm{c}}$ & $18.89 \pm 0.16^{\mathrm{b}}$ & $18.25 \pm 0.04^{\mathrm{a}}$ \\
Amylopectin (\%) & $46.53 \pm 0.12^{\mathrm{a}}$ & $48.01 \pm 0.16^{\mathrm{b}}$ & $49.94 \pm 0.13^{\mathrm{c}}$ \\
Resistant starch (\%) & $3.83 \pm 0.02^{\mathrm{b}}$ & $4.12 \pm 0.01^{\mathrm{c}}$ & $3.43 \pm 0.02^{\mathrm{a}}$ \\
Dietary fiber (\%) & $20.78 \pm 0.25^{\mathrm{c}}$ & $19.39 \pm 0.04^{\mathrm{a}}$ & $19.81 \pm 0.45^{\mathrm{b}}$ \\
Non soluble dietary fiber (\%) & $9.38 \pm 0.06^{\mathrm{c}}$ & $8.82 \pm 0.11^{\mathrm{a}}$ & $9.10 \pm 0.01^{\mathrm{b}}$ \\
Energy (cal) & $313.95 \pm 0.13^{\mathrm{b}}$ & $315.50 \pm 0.67^{\mathrm{c}}$ & $308.24 \pm 0.14^{\mathrm{a}}$ \\
\hline
\end{tabular}

Values are expressed as mean $\pm \mathrm{SD}$. Values with different superscripts within the same column are significantly different $(\mathrm{p}<0.05)$.

glycemic response, gives more prolonged satiety, and lowers colon cancer (Englyst et al., 2007; Ashraf et al., 2012). The source of the resistant starch of the analog rice comes from the modified arrowroot flour, germinated white sorghum flour and germinated red kidney beans flour. The amount of resistant starch in foods can be increased by adding legumes.

The protein content of the analog content was $8.77 \pm 0.04 \%, \quad 8.93 \pm 0.04 \%, \quad$ and $8.07 \pm 0.04 \%$ for formulation I, II and III respectively. The source of protein was derived from the germinated red kidney bean flour. Protein affects the blood glucose levels as they may decrease the glycemic response. This is because protein can lengthen the stomach's discharge rate so that the digestion rate and absorption in the small intestine are also slower (Alsaffar, 2011).

The content of the analog rice carbohydrates is relatively high in all formulations as the constituent material of analog rice is starch, which is a source of carbohydrates. The dietary fiber of the analog rice in formulation I, II and III were $20.78 \pm 0.25 \%$, $19.39 \pm 0.04 \%$, and $19.81 \pm 0.45 \%$ respectively, compared to commercial rice which is $0.8 \%$ (Liu et al., 2011).

According to Foschia et al. (2013), food is a fiber source with at least $3 \%$ of dietary fiber. While food is categorized as high in fiber if it contains dietary fiber of at least $6 \%$. Based on the statement, the resulting analog rice can be a source of dietary fiber. The fiber source was mainly obtained from the arrowroot flour, germinated red kidney bean flour and germinated white sorghum flour. Soluble dietary fibers are associated with decreased glycemic response. Soluble dietary fiber indigestion will form a gel-like texture, thus slowing digestion speed in the intestines, giving a more prolonged sense of satiety, and retarding blood glucose emergence. It can also maintain stable blood sugar levels due to insulin's need to transfer glucose into the body's cells and can be converted into less energy (Alsaffar, 2011). Insoluble dietary fiber prevents various diseases, especially those associated with the gastrointestinal tract, such as hemorrhoids, diverticulosis, and colon cancer (Eckel, 2003). According to Foster-Powell et al. (2002), rice containing high dietary fiber will lower the glycemic response, and have a low glycemic index (GI).

\section{Conclusion}

Formulation III analog rice was the best acceptable formulation selected by panelists. The high in protein and fiber analog rice can be used as a substitute of commercial rice.

\section{Conflict of Interest}

The authors do not have any conflict of interest.

\section{Acknowledgments}

The authors would like to thank the Directorate General of Higher Education of the Republic of Indonesia and Yogyakarta State University, which funded this research with contract number 06/Research/ PT/UN34.21/2019.

\section{References}

Al Dhaheri, A.S., Al Ma'awali, A.K., Laleye, L.C., Washi, S.A. and Jarrar A.H. (2015). The effect of nutritional composition on the glycemic index and glycemic load values of selected Emirati foods. $B M C$ Nutrition, 1(4), 1-8. https://doi.org/10.1186/20550928-1-4

Alsaffar, A.A. (2011). Effect of food processing on the resistant starch content of cereals and cereal products -a review. International Journal of Food Science 
Technology, 46(3), 455-462. https://doi.org/10.1111/ j.1365-2621.2010.02529.x

AOAC. (2005). Official Methods of Analysis of the Association of Official Analytical Chemist. 18th ed., Washington, DC., USA: Horwitz William Publication.

Ashraf, S., Anjum, F.M., Nadeem, M. and Riaz, A. (2012). Functional and Technological Aspects of Resistant Starch. Pakistan Journal of Food Science, 22(2), 90-95.

Audu, S.S. and Aremu M.O. (2011). Effect of Processing on Chemical composition of Red Kidney Bean (Phaseolus vulagris L.) flour. Pakistan Journal of Nutrition, 10(11), 1069-1075. https:// doi.org/10.3923/pjn.2011.1069.1075

Bisharat, G.I., Lazou, A.E., Panagiotou, N.M., Krokida, M.K. and Maroulis, Z.B. (2015). Antioxidant potential and quality characteristics of vegetableenriched corn-based extruded snacks. Journal Food Science and Technology, 52(7), 3986-4000. https:// doi.org/10.1007/s13197-014-1519-z

Budijanto, S. and Yuliana, N.D. (2015). Development of Rice Analog as a Food Diversification Vehicle in Indonesia. Journal of Developments in Sustainable Agriculture, 10, 7-14.

Eckel, R. (2003). A new look at dietary protein in diabetes. American Journal of Clinical Nutrition, 78 (4), 671-672. https://doi.org/10.1093/ajcn/78.4.671

Elkhalifa, A.E.O. and Bernhardt, R. (2010). Influence of grain germination on functional properties of sorghum flour. Food Chemistry, 121(2), 387-392. https://doi.org/10.1016/j.foodchem.2009.12.041

Englyst, H.N., Kingman, S.M. and Cummings, J.H. (1992). Classification and measurement of nutritionally important starch fractions. European Journal of Clinical Nutrition, 46(Suppl. 2), S33-S50.

Englyst, K., Liu, S. and Englyst, H.N. (2007). Nutritional Characterization and Measurement of Dietary Carbohydrates. European Journal of Clinical Nutrition, 61(1), S19-S39. https://doi.org/10.1038/ sj.ejcn.1602937

Foschia, M., Peressini, D., Sensidoni, A. and Brennan, C.S. (2013). The effects of dietary fibre addition on the quality of common cereal products. Journal of Cereal Science, 58(2), 216-227. https:// doi.org/10.1016/j.jcs.2013.05.010

Foster-Powell and Miller, J. (1995). International Tables of Glycemic Index. American Journal of Clinical Nutrition, 62(4), 871S-890S. https://doi.org/10.1093/ ajcn/62.4.871S

Hallstrom, E., Sestili, F., Lafiandra, D., Bjorck, I. and Ostman, E. (2011). A novel wheat variety with elevated content of amylose increases resistant starch formation and may beneficially influence glycaemia in healthy subjects. Food and Nutrition Research, 55, 1-8. https://doi.org/10.3402/fnr.v55i0.7074

Kaur, L., Singh, J. and Singh, N. (2005). Effect of Glycerol Monostearate on the Physic-Chemical, Thermal, Rheological and Noodle Making Properties of Corn and Potato Starch. Journal of Food Hydrocolloid, 19(5), 839-849. https:// doi.org/10.1016/j.foodhyd.2004.10.036

Lilia, B., Suman, K.T., Krishnan, S. and Indira V. (2016). Effect of autoclaving and cooling on resistant starch formation in rice starch. Asian Journal of Dairy and Food Research, 35(2), 137142. https://doi.org/10.18805/ajdfr.v35i2.10722

Liu, C., Zhang, Y., Liu, W., Wan, J., Wang, W., Wu, W., Zuo, N., Zhou, Y. and Yin, Z. (2011). Preparation, Physicochemical and Texture Properties of Texturized Rice Produce by Improved Extrusion Cooking Technology. Journal of Cereal Science, 54 (3), 473-480. https://doi.org/10.1016/ j.jcs.2011.09.001

Mishra, A., Mishra, H.N. and Rao, P.S. (2012). Preparation of Rice Analogues Using Extrusion Technology. International Journal of Food Science and Technology, 47(9), 1789-1797. https:// doi.org/10.1111/j.1365-2621.2012.03035.x

Mishra, P.K., Tripathi, J., Gupta, S. and Variyar, P.S. (2017). Effect of cooking on aroma profile of red kidney beans (Phaseolus vulgaris) and correlation with sensory quality. Food Chemistry, 215, 401-409. https://doi.org/10.1016/j.foodchem.2016.07.149

Nugraheni, M., Lastariwati, B. and Purwanti, S. (2017). Proximate and Chemical Analysis of Gluten-free Enriched, Resistant Starch Type 3 from Maranta arundinacea Flour and its Potential as a Functional Food. Pakistan Journal of Nutrition, 16(5), 322-330. https://doi.org/10.3923/pjn.2017.322.330

Ohtsubo, K., Suzuki, K., Yasui, Y. and Kasumi, T. (2005). Bio-functional Components in the Processed Pre-germinated Brown Rice by a Twin-screw Extruder. Journal of Food Composition and Analysis, 18(4), 303-316. https://doi.org/10.1016/ j.jfca.2004.10.003

Riaz, M.N. (2000). Extruders in Food Applications. Boca Raton (US): CRC Pr Inc. https:// doi.org/10.1201/9781482278859

Sai-Ut, S., Ketnawa, S., Chaiwut, P. and Rawdkuen, S. (2009). Biochemical and functional properties of proteins from red kidney, navy and adzuki beans. Journal of Agricultural and Food Industrial, 2(4), 493-504. 
Sharma, S., Saxena, D.C. and Riar, C.S. (2016). Analysing the effect of germination on phenolics, dietary fibres, minerals and $\gamma$-amino butyric acid contents of barnyard millet (Echinochloa frumentaceae). Food Bioscience, 13, 60-68. https:// doi.org/10.1016/j.fbio.2015.12.007

Subagyo, H. and Aqil, M. (2014). Perakitan dan Pengembangan Varietas Unggul Sorgum untuk Pangan, Pakan, dan Bioenergi. Iptek Tanaman Pangan, 9(1), 39-50.

Zhang, G., Xu, Z., Gao, Y., Huang, X., Zou, Y. and Yang T. (2015). Effects of Germination on the Nutritional Properties, Phenolic Profiles, and Antioxidant Activities of Buckwheat. Journal of Food Science, 80(5), H1111-9. https:// doi.org/10.1111/1750-3841.12830 